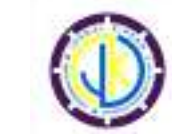

e-ISSN: 2580-6947

p-ISSN: 2354-7278

http://ojs.umrah.ac.id/index.php/kiprah/index

\title{
Problems Faced by English Teachers of Lower Secondary Schools in Assessments
}

(A Case Study in Bintan Regency)

\section{Dewi Nopita*}

\author{
Universitas Maritim Raja Ali Haji, Kota Tanjungpinang, Kepulauan Riau 29115, Indonesia
}

\begin{abstract}
Abstrak
Dalam pengajaran Bahasa Inggris, guru memegang peranan penting dalam pencapaian tujuan pembelajaran. Kemampuan guru dalam merancang proses pembelajaran sangat berpengaruh terhadap tingkat pencapaian siswa. Agar dapat meengetahui tingkat capaian pembelajaran siswa, guru diharapkan untuk mempunyai kemampuan yang baik dalam merancang penilaian. Artikel ini bertujuan untuk memaparkan masalah-masalah yang dihadapi guru Sekolah Menengah Pertama (SMP) dalam merancang penilaian proses pembelajaran yang dilakukan oleh siswa, yang merupakan hasil penelitian. Adapun data penelitian diperoleh dari guru-guru Bahasa Inggris di SMPN 17 Bintan, SMPN 3 Bintan, SMPN 2 Bintan, dan SMPN 12 Bintan melalui pengamatan dan wawancara. Hasil penelitian menunjukkan bahwa guru-guru mata pelajaran Bahasa Inggris di Kabupaten Bintan benar-benar mengalami kesulitan dalam merancang penilaian terkait bentuk dan fokus penilaian.
\end{abstract}

Kata kunci: Sekolah Menengah Pertama (SMP); guru Bahasa Inggris SMP; penilaian

\begin{abstract}
In the world of teaching English as a foreign language, teachers do hold a pivotal role in achieving the learning goals. The teachers' skill in designing their classroom instruction contributes to students' level of learning achievements. To be able to see the students' achievement in learning, English teachers are required to have knowledge and skill in designing the assessment. This article, derived from a research result, intends to explore secondary school English language teachers' problems related to English language assessment. There were 4 lower secondary schools in Bintan regency involved as the subjects of the research: SMPN 17 Bintan, SMPN 3 Bintan, SMPN 2 Bintan, and SMPN 12 Bintan. The instruments of the research were observation and interview. Finally, it was found that English language teachers of secondary schools in Bintan regency had serious problems in designing English language assessments related to the forms and the focus of the assessment.
\end{abstract}

Keywords: Lower secondary school, English teachers, assessment

\section{Introduction}

Designing English language assessments is one of pedagogical skill which all English teachers need to be able to. An ideal English language assessment should meet 5 criteria: (1) practicality, (2) validity, (3) reliability, (4) authenticity, and (5) washback. Practicality deals with the cost, the instructions, the duration, and the scoring/ evaluation procedure of a test. Then, validity

*Penulis Korepondensi

Email Address : dewinopita.umrah@gmail.com is the extent to which inferences made from assessment results are appropriate, meaningful, and useful in terms of the purpose of the assessment. The third principle, reliability, is a test has to consistently yield the same results in a given population. The test components (directions/ rubrics), the students, the scoring, the test administration, and the test itself are variables of reliability. Next, authenticity is 
how well the characteristics of the test correlate to the native language (target language); how likely the language tasks will actually be performed in the real world. The last, washback is the feedback that a test gives to both the test takers and the test developers (Brown, 2004; Gronlund, 1998).

For lower secondary schools, the good assessment is designed not only to meet the 5 criteria but also to suit the students' characteristics which obviously influence their learning attitude as well as affects their achievement. The students' characteristics that should be considered are physical development, intellectual development, moral reasoning, spiritual development, and psychological needs (Stevenson, 2002; Scales, 2010; Kellough\&Kellough, 2008). The teachers' consideration of these characteristics help students feel safe and sound in facing any form of English language assessment.

Furthermore, in lower secondary schools, like any other level of education, assessment becomes a crucial part in teaching English. This is due to what students have learnt cannot be estimated with any amount of certainty. Assessment therefore is to bridge the gap between learning and teaching. Any student taking any form of learning would be, in one form or another, subject to assessment. Brown (2004) explains that assessments include test and task. Test belongs to formal assessment while task belongs to informal one. A welldesigned test can act as an engine which finally derives active student learning (Cowan, 2005).

In reality, to design a good English language assessment is an extremely difficult task for English teachers of lower secondary schools (Sekolah Menengah Pertama) in Bintan regency. This is mainly caused by a gap existing between curriculum focus and final exam (Ujian National) focus. The curriculum (K13) requires English teachers to have focus on affective, psychomotoric, and cognitive aspects while national exam (UN) focus on not more than cognitive aspect. It indicates that the learning process focusing more on building a good soft skill contributes less to students' success in facing UN. Finally, it goes without saying that this condition puts English teachers in a dilemmatic situation. In other words, the teachers are in dilemma of obeying the curriculum requirements or helping students face the national exam (UN) as the final assessment of the entire English language learning process. This article aims at exploring problems faced by English language teachers of lower secondary schools in Bintan regency in designing English language assessments.

\section{Research Method}

This is a descriptive qualitative research because it describes English language teachers' problems in designing English language assessments for lower secondary schools. Gay (1987) points out that the descriptive research involves collecting data in order in order to get hypothesis or to answer questions concerning the status of the subject of the study. The subjects of the research were 10 English language teachers of 4 lower secondary schools in Bintan regency: SMPN 17 Bintan, SMPN 3 Bintan, SMPN 2 Bintan, and SMPN 12 Bintan. In collecting the data, observation and interview were used. The results of the observation and the interview described and analyzed. Finally, the researcher interpreted the collected data critically based on the facts found in the field (Gay, 1987).

\section{Results and Discussion}

The problems were identified by using two instruments, there were interview and observation. The findings of these two instruments are presented below: 


\section{a. Interview Findings}

The interview result showed that there were five major problems faced by the teachers which can be seen in the following table.

Tabel 1.

Problems Faced by English Language Teachers of Lower Secondary Schools in Bintan Regency in Assessment

\begin{tabular}{|l|l|c|}
\hline No & \multicolumn{1}{|c|}{ Problems } & \multicolumn{1}{|c|}{$\begin{array}{l}\text { Number of } \\
\text { Teacher }\end{array}$} \\
\hline 1 & $\begin{array}{l}\text { The teachers got problems in } \\
\text { employing different forms of } \\
\text { assessment because the } \\
\text { students have a very limited }\end{array}$ & $9(90 \%)$ \\
$\begin{array}{l}\text { English vocabulary and a very } \\
\text { low motivation in learning }\end{array}$ & $\begin{array}{l}\text { English. } \\
\text { The teachers do not have } \\
\text { authority to be creative in } \\
\text { designing the assessments } \\
\text { because everything is ruled by } \\
\text { the curriculum. } \\
\text { The teachers do not take all } \\
\text { criteria of a good assessment } \\
\text { and students characteristics } \\
\text { into account in designing the } \\
\text { assessment. } \\
\text { The teachers do not have } \\
\text { adequate knowledge about } \\
\text { English language assessment } \\
\text { because some of them are not } \\
\text { from English department and } \\
\text { because they do not have } \\
\text { opportunity to upgrade their } \\
\text { knowledge. } \\
\text { The teachers are confused of } \\
\text { how to design affective } \\
\text { English language assessments } \\
\text { to make the curriculum focus } \\
\text { and UN focus in balance }\end{array}$ & $10(100 \%)$ \\
\end{tabular}

In Sekolah Menengah Pertama (SMP) in Bintan regency, most English language teachers did have problems with assessments. The problems are related to the forms and the focus of the assessments. These problems are mainly due to the students' and the teachers' factors. The students' factors are their lack of vocabulary mastery and their low motivation to learn English which is assumed to be the results of inappropriate English language instruction. To minimize the problems caused by the students, English language teachers need to consider the students' characteristics (see
Stevenson, 2002; $\quad$ Scales, 2010; Kellough\&Kellough, 2008).

Then, from the teachers' side, the problems arise for some reasons. First of all, the teachers do not know how to design English language assessments which give positive impact to both the instructional goals required by the curriculum and the national exam (UN). It was stated previously that English language teachers are required to assess their students' affective, psychomotoric, and cognitive aspects during the teaching process. However, this not in line with what is tested in UN which focus only on the cognitive aspect. Another reason is that English language teachers' cannot be creative in designing the assessment because the assessments are ruled by $\mathrm{K} 13$ curriculum. In K13 curriculum, the assessments should be based on the implemented teaching models (discovery learning, inquiry, project-based learning, and problems-based learning). The next reason is that in designing the assessments, the teachers do not consider the good English language assessment criteria and the students' characteristics. It indicates that the teachers are not aware that the two aspects are very crucial in the students' success. The last is that the teachers have lack of opportunity to improve their knowledge and skill in designing English language assessments. Even, some of them are not from English education department.

\section{b. Observation Findings}

The findings of observation are in line with interview findings. The English language teachers' problems of secondary schools in Bintan regency in designing English language assessment was as follows:

1. One teacher assessed students' English language skill in various ways.

2. $50 \%$ of the teachers only assessed what they have taught.

3. More than $50 \%$ of the assessment results were inconsistent.

4. More than $50 \%$ of the teachers did not assess students' learning progress in a conducive learning atmosphere. 
JURNAL KIPRAH, Desember 2018; V1(2): 17-20

e-ISSN: 2580-6947

p-ISSN: 2354-7278

5. More than $50 \%$ of the teachers did not assess students' English language progress authentically.

Seemingly, the focus of the English language assessments designed by the teachers was still murky. It implied that the assessments did not have positive washback. The facts have shown that the UN could not be used as a consideration in designing English language assessment in the form of task and test during the teaching process. The assessments employed during the teaching and learning process focus more on affective aspects while UN focus only on cognitive aspects. This problematic condition has become a serious burden that the teachers have to deal with which then also affect their teaching process as a whole.

In addition, the facts have shown that the teachers only assessed what they have taught and the results of the assessments are inconsistent. In lower secondary schools in Bintan regency, most English language teachers used several printed textbooks which are not written by the teachers themselves in teaching. The students only learnt the materials available in the books and the teachers assessed the students' understanding about the materials. It seems that the books are written based on K13 curriculum but not meet the UN requirements. This made the students' UN scores at the end of the entire learning process lower than what they normally achieved.

The inconsistent results of the assessment proved that the assessments were not reliable (Brown, 2004). In this case, the teachers need to assess their students in a conducive learning atmosphere. Moreover, to achieve the reliability, the teachers are supposed to care of the students' physical or psychological factors, such as the students' temporary illness, fatigue, a "bad day" and anxiety. Then, the teachers need to create a rubric for each assessment. 